\title{
PENGARUH KEPEMIMPINAN DAN MOTIVASI TERHADAP KINERJA KELOMPOK TANI PADI PANDANWANGI (STUDI KASUS DI DESA TEGALEGA KECAMATAN WARUNGKONDANG KABUPATEN CIANJUR)
}

\author{
Oleh: \\ Rahmat Taufiq Dwi Jatmika*) \\ Gista Aulia Dewi**)
}

\begin{abstract}
Abstrak
Salah satu aspek dalam peningkatan kinerja kelompok tani adalah berjalannya kepemimpinan ketua kelompok dalam kelompok tani itu sendiri. Tujuan penelitian ini: (1) untuk mengetahui pengaruh kepemimpinan terhadap kinerja kelompok tani, (2) untuk mengetahui pengaruh motivasi terhadap kinerja kelompok tani, (3) untuk mengetahui pengaruh kepemimpinan dan motivasi terhadap kinerja kelompok tani. Penelitian ini dilaksanakan dari bulan Februari sampai dengan bula Juni 2019 di Desa Tegallega Kecamatan Warungkondang. penelitian ini merupakan penelitian kuantitatif. Analisis yang digunakan yaitu deskriptif, metode pengolahan data sebagai berikut : (1) Regresi linier berganda, (2) Uji T, (3) Uji F. Berdasarkan hasil analisis regresi linier berganda menunjukan nilai $0,000<0,10$ ( $\alpha$ ) dan nilai thitung 1.943 lebih besar> dari ttabel 1.7032. hasil uji $F$ menunjukan Variabel kepemimpinan dan variabel motivasi berpengaruh secara simultan dengan nilai Fhitung lebih besar> dari Ftabel sebesar 25,176 dengan nilai signifikan 0,000 terhadap kinerja. Hasil tersebut menunjukan, terdapat pengaruh yang signifikan antara kepemimpinan dan motivasi terhadap kinerja kelompok tani di Desa Tegallega Kecamatan Warungkondang.
\end{abstract}

Kata Kunci : Kepemimpinan ketua kelompok, motivasi terhadap kinerja, korelasi, regresi.

\begin{abstract}
One aspect of improving the performance of farmer groups is the leadership of the group leaders in the farmer groups themselves. The purpose of this study: (1) to determine the effect of leadership on the performance of farmer groups, (2) to determine the effect of motivation on the performance of farmer groups, (3) to determine the effect of leadership and motivation on the performance of farmer groups. This research was conducted from February to June 2019 in Tegallega Village, Warungkondang District. this research is quantitative research. The analysis used is descriptive, data processing methods are as follows: (1) Multiple linear regression, (2) $T$ test, (3) F test. Based on the results of multiple linear regression analysis shows the value of $0,000<0.10$ (a) and the value of $t$ the 1.943 count is greater than the table 1.7032. F test results show leadership variables and motivation variables simultaneously influence the Fcount value greater than Ftable of 25.176 with a significant value of 0.000 on performance. These results indicate, there is a significant influence between leadership and motivation on the performance of farmer groups in Tegallega Village, Warungkondang District.
\end{abstract}

Keywords: Leadership of group leaders, motivation on performance, correlation, regression.

*) Dosen Fakultas Sains Terapan UNSUR

**) Alumni Fakultas Sains Terapan UNSUR

\begin{tabular}{|c|c|c|}
\hline PENGARUH & KEPEMIMPINAN & RAHMAT TAUFIQ DW JATMIKA dan GISTA AULIA \\
\hline MOTIVASI & TERHADAP & \\
\hline \multicolumn{3}{|c|}{ KELOMPOK TANI PADI PANDANWANGI } \\
\hline $\begin{array}{l}\text { (STUDI KASUS } \\
\text { KECAMATAN }\end{array}$ & $\begin{array}{c}\text { DI } \begin{array}{c}\text { DESA TEGALEGA } \\
\text { WARUNGKONDANG }\end{array}\end{array}$ & \\
\hline KABUPATEN CIA & $\begin{array}{l}\text { WARUNGKONDANG } \\
\text { ANIUR) }\end{array}$ & \\
\hline
\end{tabular}




\section{PENDAHULUAN}

Sumber daya manusia merupakan faktor yang cukup berperan dalam keberhasilan suatu kelompok, karena orang yang ada dalam kelompok tersebut yang menjalankan kelompoknya. Pengembangan sumber daya manusia ini menjadi salah satu upaya untuk menghadapi tantangan yang berkaitan dengan perubahan lingkungan. Terkait hal tersebut, pemimpin juga berperan dalam mengelola sumber daya manusia, yaitu anggotanya. Seorang pemimpin dapat memberikan kebebasan setiap anggota untuk berpikir agar semua anggota mengalami proses perubahan untuk bisa menyelesaikan masalah. Pemimpin kelompok berperan pula dalam menggerakkan keaktifan kelompok tani.

Kelompok tani adalah kelembagaan petanian atau peternak yang dibentuk atas dasar kesamaan kepentingan, kesamaan kondisi lingkungan (sosial, ekonomi dan sumberdaya) dan keakraban untuk meningkatkan dan mengembangkan usaha anggotanya serta ditumbuhkembangkan dari, oleh dan untuk petani yang saling mengenal, akrab, saling percaya, mempunyai kepentingan dalam berusahatani, kesamaan baik dalam hal tradisi, pemukiman, maupun hamparan lahan usahatani (Pusat Penyuluhan Pertanian, 2012).

Setiap orang mempunyai pengaruh atas orang lain, dengan pengetahuan yang luas maka pengaruh tersebut akan berkembang dan bertambah. Kepemimpinan membutuhkan kemampuan untuk mempengaruhi seseorang dalam mewujudkan tujuan yang akan dicapai. Menurut Gary Yukl, (2009) mengatakan bahwa : Kepemimpinan adalah kemampuan individu untuk mempengaruhi, memotivasi, dan membuat orang lain mampu memberikan kontribusinya demi efektivitas dan keberhasilan organisasi. Jadi dari pendapat tersebut dapat dikatakan bahwa kepemimpinan merupakan cara mempengaruhi dan memotivasi orang lain agar orang tersebut mau berkontribusi untuk keberhasilan organisasi. Sedangkan menurut Matondang (2008) Kepemimpinan adalah suatu proses dalam mempengaruhi orang lain agar mau atau tidak melakukan sesuatu yang diinginkan.

Seperti hal nya seorang pemimpin kelompok tani harus mempunyai wawasan yang luas memiliki kejujuran dan bijaksana dalam memimpin anggota kelompoknya, sehingga dapat mewujudkan petani yang berkualitas antara lain dicirikan oleh adanya kemandirian dan ketangguhan dalam berusahatani. Salah satu faktor penting untuk terwujudnya kelompok yang efektif adalah berjalannya kepemimpinan dari pemimpin kelompok tersebut. Menurut Mulyadi dan Rivai (2011), kepemimpinan harus berfungsi secara baik untuk diwujudkan dalam interaksi sosial sebuah kelompok atau organisasi. Dengan berjalannya kepemimpinan di kelompok, maka akan dimungkinkan kelompok tersebut mencapai kemandirian, kemandirian anggota kelompok adalah tingkat keberhasilan untuk mencapai tujuannya.

Desa Tegalega terletak Kecamatan Warungkondang Kabupaten Cianjur memiliki luas Desa 1000.350 Ha dengan populasi penduduk 4.848 jiwa dan jumlah KK sebesar 1,632 KK, yang sebagian besar penduduknya bermata pencaharian sebagai petani padi Pandanwangi. Desa Tegalega mempunyai 8 kelompok tani yang sebagian besar membudidayakan padi Pandanwangi. Desa Tegalega merupakan salah satu Desa yang mempunyai lahan padi Pandanwangi terbesar di Kecamatan Warungkondang. Desa Tegalega mempunyai lahan sawah padi Pandanwangi seluas $10 \mathrm{H}$. Lahan sawah di Desa Tegalega merupakan salah satu sentral padi Pandanwangi yang terluas di Kecamatan Warungkondang. Desa Tegalega membudidayakan padi Pandanwangi dengan cara convensional.

Peran ketua kelompok tani di Desa Tegalega tersebut sangatlah 
berpengaruh terhadap keberhasilan budidaya dan pemasaran padi Pandanwangi. Walau demikian jumlah petani padi Pandanwangi cenderung menurun karena dilihat dari jangka waktu tanam yang lama. Jika dilihat dari harga, hanya beberapa daerah yang bisa ditanami padi Pandanwangi.

Maka dari itu penulis tertarik melakukan penelitian dengan judul " Pengaruh Kepemimpinan Dan Motivasi Terhadap Kinerja Kelompok Tani Padi Pandanwangi Di Desa Tegalega Kecamatan Warungkondang" Karena Desa Tegalega menjadi salah satu sentral produksi padi Pandanwangi terbesar di Kecamatan Warungkondang dan petani padi Pandanwangi tersebut.

\section{METODE PENELITIAN}

\section{Waktu dan Tempat Penelitian}

Penelitian dilaksanakan di Desa Tegalega Kecamatan Warungkondang Kabupaten Cianjur. Pemilihan lokasi ini dilakukan secara purposive sampling atau sengaja karena daerah ini terdapat Kelompok tani yang membudidayakan padi Pandanwangi. Waktu penelitian dilaksanakan pada bulan Februari sampai dengan bulan Juni 2019.

\section{Jenis dan Sumber Data}

\section{Data Primer}

Data primer adalah sumber data yang diperoleh secara langsung dari sumber asli (tidak melalui perantara). Data ini dapat berupa opini subyek (orang) secara individual/kelompok, hasil observasi terhadap suatu benda (fisik), kegiatan / kejadian dan hasil pengujian (Sugiyono, 2015). Data ini diperlukan untuk mengetahui seberapa besar pengaruh kepemimpinan dan motivasi kerja terhadap kinerja kelompok tani yang dapat dilihat dengan cara ketua kelompok tani tersebut memberikan pengarahan langsung kepada anggota kelompok tani tersebut. Untuk mendapatkan data dan informasi yang diinginkan akan diberikan kuesioner kepada anggota kelompok tani.

\section{Data Sekunder}

Data Sekunder adalah data yang diperoleh atau dikumpulkan oleh orang yang melakukan penelitian dari sumbersumber yang telah ada (moleong 2012). Data ini digunakan untuk mendukung informasi primer yang telah diperoleh yaitu dari bahan pustaka, literatur, penelitian terdahulu, buku, dan lain sebagainya.

\section{Teknik Pengumpulan Data}

Sugiono (2010) menjelaskan bahwa pengumpulan data dapat dilakukan dalam berbagai setting, berbagai sumber dan berbagai cara . Bila dilihat dari setting-nya, data dapat dikumpulkan pada setting ilmiah(natural setting) atau survey. Bila dilihat dari sumber data, maka pengumpulan data dapat menggunakan sumber primer dan sumber sekunder. Selanjutnya bila dilihat dari segi cara atau teknik pengumpulan data, maka teknik pengumpulan data dapat dilakukan dengan observasi, wawancara, kuesioner, studi literatur dan dokumentasi.

\section{Observasi}

Observasi adalah teknik pengumpulan data yang dilakukan melalui suatu pengamatan, dengan disertai pencatatan terhadap keadaan atau perilaku objek sasaran (Fatoni, 2006 ). Observasi ini dilakukan untuk mendapatkan data dan informasi tentang seberapa besar pengaruh kepemimpinan dan motivasi terhadap kinerja kelompok tani di Desa Tegalega.

\section{Wawancara}

Sugiono (2011), menjelaskan bahwa wawancara merupakan pertemuan dua orang untuk bertukar informasi dan ide melalui tanya jawab, sehingga dapat dikonstruksikan makna dalam suatu topik tertentu. Pada penelitian ini wawancara ditujukan untuk anggota kelompok tani . Tujuannya untuk mengetahui seberapa

PENGARUH
KEPEMIMPINAN
MOTIVASI DAN
TERHADAP
KELOMPOK TANI PADI PANDANWANGI
(STUDI KASUS DI DESA TEGALEGA
KECAMATAN
KABUPATEN CIANJUR)


besar pengaruh kepemimpinan kelompok tani di Desa Tegalega.

\section{Studi Dokumentasi}

Studi Dokumentasi merupakan teknik pengumpulan data dengan acuan dokumen bentuk tulisan dan gambar. Pengumpulan data yang menggunakan alat berupa kamera dari handphone untuk mendokumentasikan kegiatan-kegiatan penelitian.

\section{Angket (Kuesioner)}

Angket adalah suatu alat pengumpulan informasi dengan cara menyampaikan sejumlah pertanyaan tertulis untuk dijawab pula oleh responden, (Margono, 2000). Angket ini digunakan untuk mengetahui seberapa besar pengaruh ketua kelompok tani dalam memberi motivasi kepada anggota kelompok tani. Alasan menggunakan teknik ini agar responden lebih leluasa dalam menjawab pertanyaan yang diajukan.

\section{Populasi dan Sampel}

Populasi adalah suatu himpunan unit yang biasanya berupa orang, objek, transaksi atau kejadian di mana kita tertarik untuk mempelajarinya (Sugiyono, 2015). Populasi dalam penelitian ini adalah anggota kelompok tani di Desa Tegalega yang mempunyai 8 kelompok tani masing - masinng berjumlah 30 orang jumlah keseluruhan dari anggota kelompok tani ada 24 anggota kelompok.

Untuk melakukan sebuah penelitian, seorang peneliti tidak harus meneliti keseluruhan anggota populasi yang ada. Peneliti dapat memilih beberapa orang yang dianggap dapat mewakili populasi tersebut. Sampel adalah bagian dari jumlah dan karakteristik yang dimiliki oleh populasi (Sugiyono, 2015).

\section{Variabel Penelitian}

Variabel kepemimpinan (X1) menurut Weschler dan Massarik dalam Prasetyo Heru Stefanus (2015), kepemimpinan adalah pengaruh antar pribadi yang dijalankan suatu situasi tertentu. Serta diarahkan melalui proses komunikasi, kearah pencapaian satu atau beberapa tujuan.

Indikator dalam kepemimpinan antara lain: ketua kelompok sebagai motivator, mengalami pengetahuan yang luas tentang padi Pandanwangi, memiliki komitmen mengembangkan padi Pandanwangi.

Variabel motivasi (X2) menurut (Samsudin, 2010) mengemukakan bahwa motivasi adalah proses mempengaruhi atau mendorong dari luar terhadap seseorang atau kelompok kerja agar mereka mau melaksanakan sesuatu yang telah di tetapkan.

Indikator motivasi anatara lain: Intensitas pertemuan dengan ketua kelompok dan bertukar pikiran.

Variabel kinerja menurut (Hasibuan , 2006) mengemukakan kinerja adalah suatu hasil kerja yang dicapai seseorang dalam melaksanakan tugas - tugas yang di bebankan kepadanya yang didasarkan atas kecakapan, pengalaman dan kesungguhan serta waktu.

Indikator kinerja anatara lain: minat menanam padi Pandanwangi, melakukan budidaya padi Pandanwangi dan peningkatan hasil panen padi Pandanwangi.

\section{Operasional Variabel}

Variabel penelitian ini terdiri dari dua macam variabel, yaitu variabel terikat (dependent variable) atau variabel yang tergantung dengan variabel yang lainnya serta variabel bebas (independent variable) atau variabel yang tidak memiliki ketergantungan terhadap variabel lainnya. Variabel terikat dalam penelitian ini adalah kepemimpinan dan motivasi anggota kelompok tani di Desa Tegalega Kecamatan Warungkondang. Variabel bebas dari penelitian ini adalah kinerja dari anggota kelompok tani di Desa Tegalega Kecamatan Warungkondang. 
sudah dapat dipercaya, yang reliabel akan menghasilkan data yang dapat dipercaya juga. Apabila datanya memang benar sesuai dengan kenyataan, maka berapa kali pun diambil tetap akan sama. Reliabilitas menunjukkan pada tingkat keterandalan sesuatu. Reliabel artinya dapat dipercaya jadi dapat diandalkan,(Arikunto, 2012).

Uji realibilitas dari setiap konstruk yang digunakan dalam penelitian ini menggunakan metode Cronbach's Alpha dengan bantuan software SPSS 15.0. Cronbach Alpha yang cukup dapat diterima adalah yang bernilai 0.60 sampai 0.70 atau lebih (Sekaran, 2004). Dasar pengambilan keputusan uji reabilitas untuk instrumen yang reliabel adalah sebagai berikut:

- Jika Cronbach's coefficient alpha (a) > 0.6 maka cronbach's alpha acceptable (construct reliable) atau pernyataan dalam kuesioner layak digunakan.

- Jika Cronbach's coefficient alpha (a) < 0.6 maka cronbach's alpha acceptable (construct reliable) atau pernyataan dalam kuesioner tidak layak digunakan.

\section{Analisis Regresi Berganda}

Data analisis ini adalah kuantitatif dan deskriptif. Dalam penelitian ini menggunakan metode analisis regresi linier berganda. Analisis regresi linier berganda adalah regresi linier untuk menganalisis besarnya hubungan dan pengaruh variabel independent yang jumlahnya lebih dari dua (Suhardi dan Purwanto, 2004).

Menurut Suhardi dan Purwanto 2011, ada persamaan model regresi linier berganda yaitu :

$\mathrm{Y}=\mathrm{a}+\mathrm{b} 1 \mathrm{X} 1+\mathrm{b} 2 \mathrm{X} 2+\ldots+\mathrm{bkXk}$

Keterangan :

$\mathrm{Y} \quad$ : nilai prediksi dari $\mathrm{Y}$

a : bilangan konstan

b : koefisien variabel bebas

$\mathrm{X} 1, \mathrm{X} 2$ : variabel independent

$\mathrm{X} 1$ : kepemimpinan

$\mathrm{X} 2$ : motivasi

\section{Uji Koefisien Regresi Secara Parsial} (Uji t )

Uji ini digunakan untuk mengetahui dalam model regresi variabel independen secara parsial berpengaruh signifikan terhadap variabel dependen $(\mathrm{Y})$.

Jika nilai signifikansi $<0,10$ atau $\mathrm{t}_{\text {hitung }}>$ $\mathrm{t}$ tabel maka terdapat pengaruh variabel $\mathrm{X}$ terhadap $\mathrm{Y}$ dan nilai signifikansi $>0,10$ atau $\mathrm{t}$ hitung $<\mathrm{t}$ tabel maka tidak terdapat pengaruh variabel $\mathrm{x}$ terhadap $\mathrm{Y}$. Adapun rumus untuk mencari $t$ tabel sebagai berikut :

$\mathrm{t}$ tabel $=\mathrm{t}(\mathrm{a} / 2: \mathrm{n}-\mathrm{k}-1)=\mathrm{t}$

Keterangan :

$\mathrm{a}=$ tingkat kepercayaan

$\mathrm{n}=$ jumlah sampel

$\mathrm{k}=$ jumlah variabel $\mathrm{X}$

\section{Uji Koefisien Secara Simultan (Uji} F)

Uji ini digunakan untuk mengetahui seberapa besar variabel independen $(\mathrm{X})$ secara bersama-sama berpengaruh signifikan terhadap variabel dependen $(\mathrm{Y})$ atau mengetahui model regresi dapat digunakan untuk memprediksi variabel dependen atau tidak.

Jika nilai signifikansi $<0,05$ atau $f$ hitung $>\mathrm{f}_{\text {tabel }}$ maka terdapat pengaruh variabel X secara simultan terhadap $\mathrm{Y}$ dan nilai signifikansi $>0,05$ atau $\mathrm{t}_{\text {hitung }}<$ $\mathrm{t}$ tabel maka tidak terdapat pengaruh variabel $\mathrm{x}$ secara simultan terhadap $\mathrm{Y}$. Adapun rumus untuk mencari $f$ tabel sebagai berikut :

$\mathrm{F}$ tabel $=\mathrm{F}(\mathrm{k}: \mathrm{n}-\mathrm{k})=\mathrm{F}$

Keterangan :

$\mathrm{n}=$ jumlah sampel

$\mathrm{k}=$ jumlah variabel $\mathrm{X}$

\section{HASIL DAN PEMBAHASAN}

\section{Gambaran Umum Desa Tegallega}

Desa Tegalega berada di

Kecamatan Warungkondang luas desa Tegalega 1000,350 ha. Desa Tegalega memiliki 6RW serta 26 RT. Batasan Desa Tegalega : Sebelah Utara terdapat Desa Bunikasih, Sebelah Timur terdapat Desa

PENGARUH
KEPEMIMPINAN
MOTIVASI DAN
KELOMPOK TANI PADI PANDANWANGI
(STUDI KASUS DI DESA TEGALEGA
KECAMATAN
KABUPATEN CIANJUR)


Mekarwangi, Sebelah Selatan terdapat Kabupaten Bogor dan Sebelah Barat terdapat Desa Bunisari.

Jumlah penduduk Desa Tegalega yaitu 4.848 jiwa yang lebih banyak yang lebih banyak bermata pencaharian sebagai petani 246 jiwa, buruh tani 454 jiwa, karyawan 290 jiwa, wiraswasta 4 jiwa, pertukangan 14 jiwa, pensiunan 15 jiwa, dan jisa 29 jiwa.

Pada luas dan hasil tanaman sayuran adalah $50 \mathrm{Ha} 75$ Ton, buah - buahan 6 $\mathrm{Ha} 60$ Ton, padi dan palawija $94 \mathrm{Ha} 450$ Ton. Padi pandanwangi adalah salah satu padi yang ditanam di desa Tegallega yang mempunyai tekstur tanah pada sawah yang sangat cocok di tanami padi pandanwangi.

Desa Tegallega mempunyai 8 kelompok tani antara lain : kelompok tani Sari Tani, Karya Barokah, Mayang Warna, Sari
Barokah, Mitra Tani Parahiyangan, Mitra Tani Parahiyangan II, Mekar Tani dan Jasa Tani Mandiri. Dari 8 kelompok tani tersebuta hanya 5 kelompok tani yang membudidayakan padi dan 3 kelompok tani membudidayakan hortikultura.

\section{Struktur Organisasi Kelompok tani di Desa Tegallega}

Kepengurusan kelompok tani di Desa Tegallega dibentuk berdasarkan hasil dari musyawarah dan mufakat bersama, berlandaskan kepercayaan dari masingmasing anggota kelompok tani. Dengan tujuan untuk mempermudah pencapaian tujuan bersama, menjalin kerjasama dan meningkatkan sinergitas dan solidaritas dalam dinamika kelompok tani. Berikut adalah Struktur Organisasi Kelompok Tani di Desa Tegallega:

1. Struktur Organisasi Kelompok Tani Sari Tani

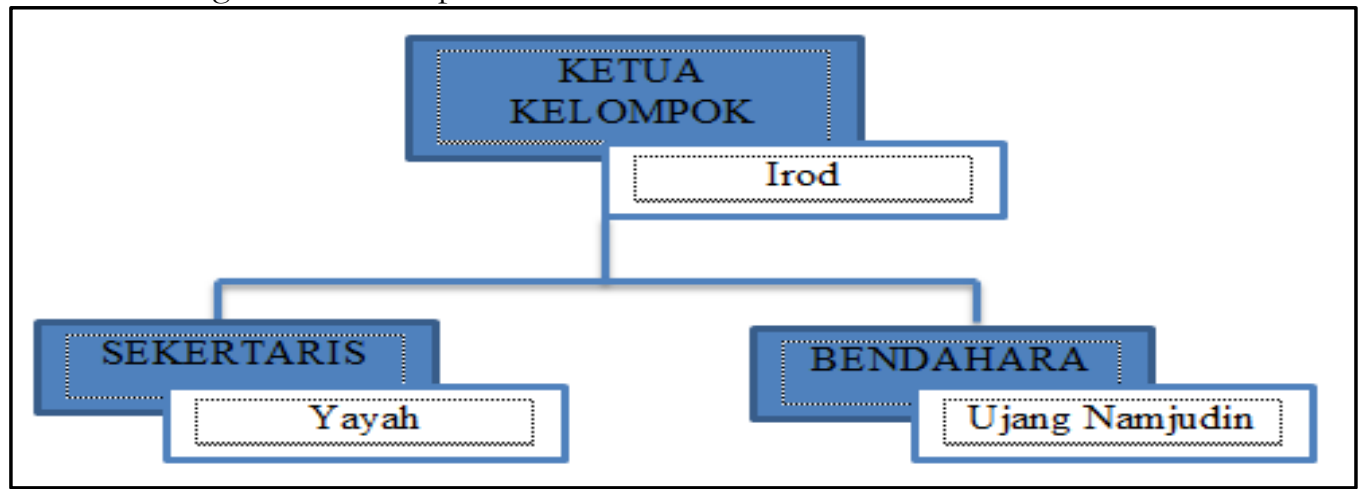

Gambar 1. Struktur Organisasi Kelompok Tani Sari Tani.

2. Struktur Organisasi Kelompok Tani Karya Barokah

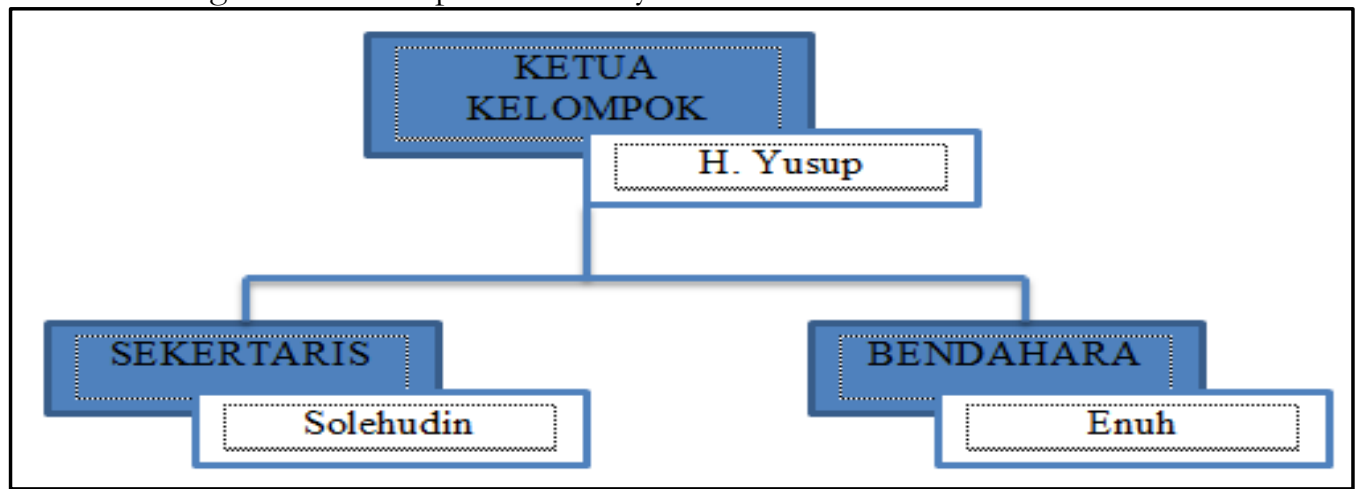

Gambar 2. Struktur Organisasi Kelompok Tani Karya Barokah.

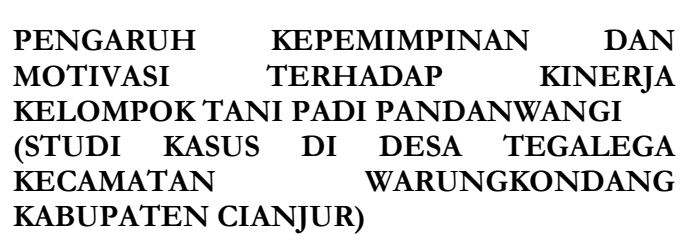


3. Struktur Organisasi Kelompok Tani Mayang Warna

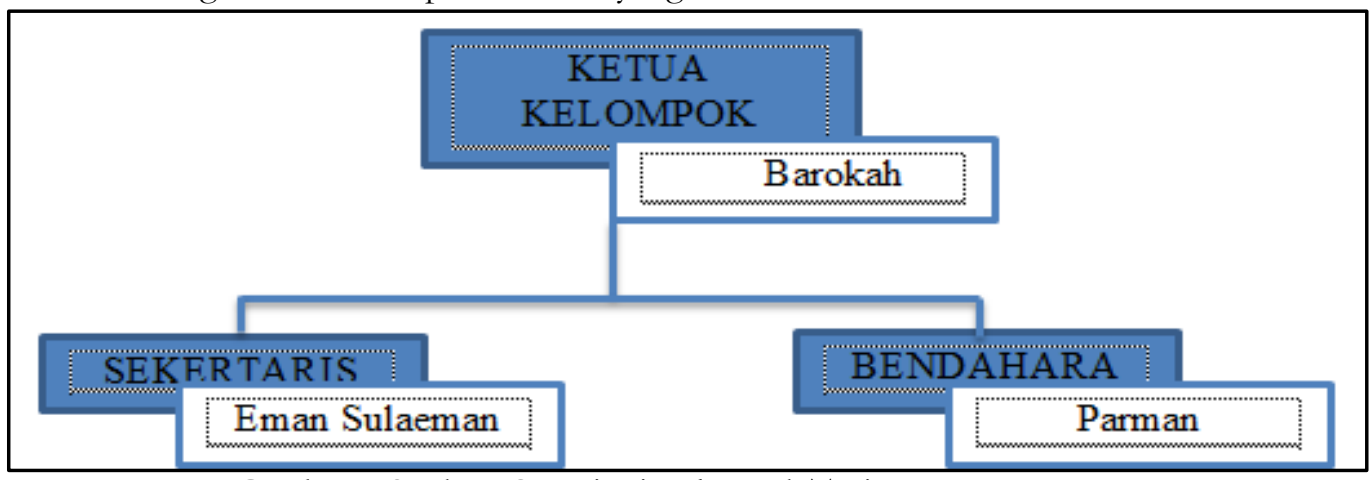

Gambar 3. Struktur Organisasi Kelompok Tani Mayang Mawarna.

4. Struktur Organisasi Kelompok Tani Sari Barokah

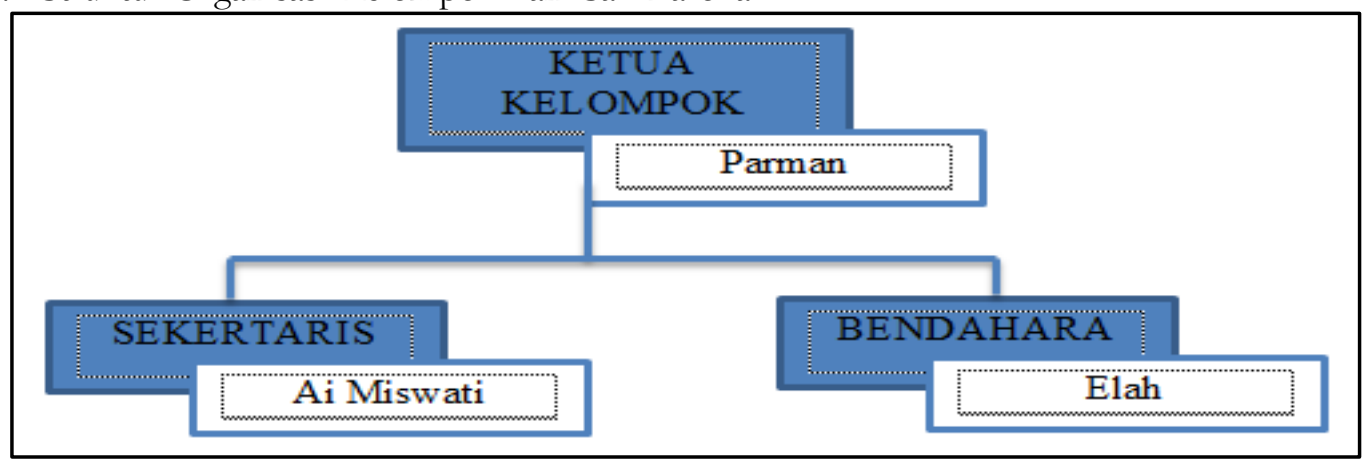

Gambar 4. Struktur Organisasi Kelompok Tani Sari Barokah.

5. Struktur Organisasi Kelompok Tani Mekar Tani.

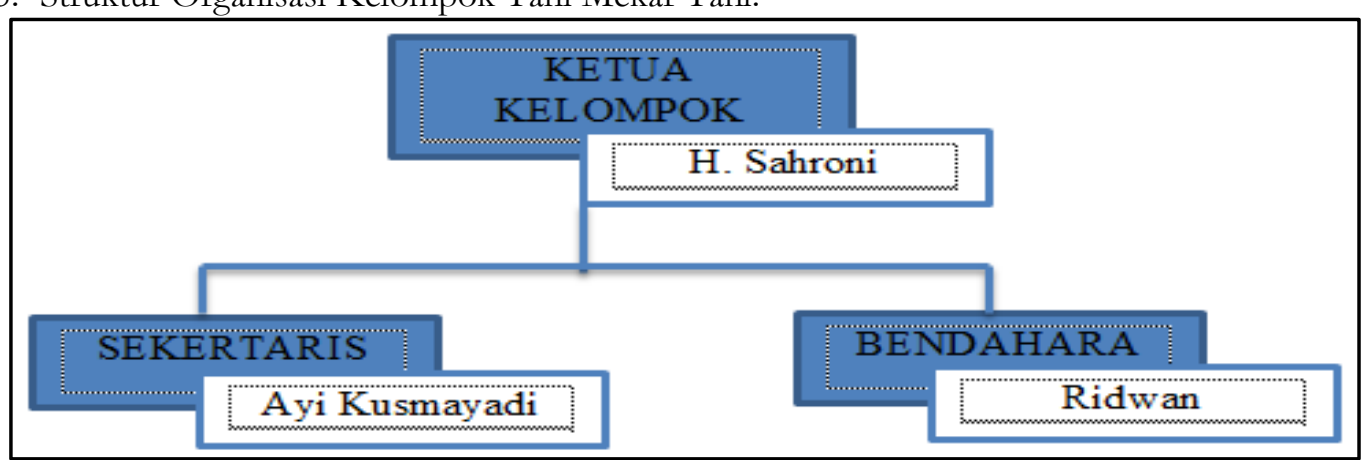

Gambar 5. Struktur Organisasi Kelompok Tani Mekar Tani.

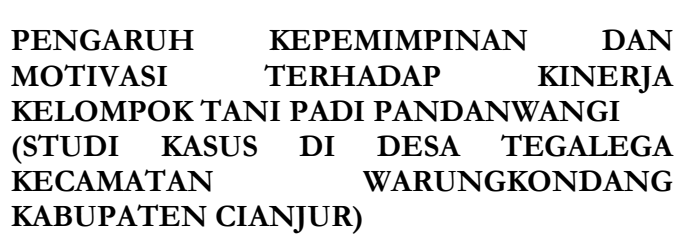


Tabel 2. Daftar Nama anggota kelompok tani di Desa Tegallega.

\begin{tabular}{clccll}
\hline No & \multicolumn{1}{c}{ Nama } & $\begin{array}{c}\text { Usia } \\
\text { (Tahun) }\end{array}$ & $\begin{array}{c}\text { Pendidikan } \\
\text { Terakhir }\end{array}$ & $\begin{array}{c}\text { Kelompok } \\
\text { tani }\end{array}$ & Alamat \\
\hline 1. & Dayat & 57 & SD & Mayang Warna & Kp. Pasir Angin \\
2. & Parman & 50 & SD & Mayang Warna & Kp.Pasir Angin \\
3. & Dayi & 39 & SD & Mayang Warna & Kp. Pasir Angin \\
4. & Enung & 60 & SD & Karya Barokah & Kp. Haur Seah \\
5. & Cuce & 55 & SD & Karya Barokah & Kp. Haur Seah \\
6. & Wahyu & 63 & SD & Karya Barokah & Kp. Haur Seah \\
7. & Dudu & 57 & SD & Karya Barokah & Kp. Haur Seah \\
8. & Jajang & 22 & SMA & Karya Barokah & Kp. Haur Seah \\
9. & Ayim & 42 & SD & Karya Barokah & Kp. Haur Seah \\
10. & Enuh & 50 & SD & Karya Barokah & Kp. Haur Seah \\
11. & Dama & 61 & SD & Karya Barokah & Kp. Haur Seah \\
12. & Ece & 58 & SD & Karya Barokah & Kp. Haur Seah \\
13. & Harun & 50 & SD & Karya Barokah & Kp. Haur Seah \\
14. & Ayi & 23 & SMA & Sari Barokah & Kp. Loji \\
15. & Awud & 30 & SD & Sari Barokah & Kp. Loji \\
16. & H. Taufik & 55 & SD & Sari Barokah & Kp. Loji \\
17. & Kayi & 55 & SD & Sari Barokah & Kp. Loji \\
18. & Aji & 57 & SD & Sari Barokah & Kp. Loji \\
19. & Ai Miswati & 27 & SD & Sari Barokah & Kp. Loji \\
20. & Abdullah & 35 & SD & Sari Barokah & Kp. Loji \\
21. & Elah & 44 & SD & Sari Barokah & Kp. Loji \\
22. & Endang & 54 & SD & Sari Tani & Kp. Sawah Lega \\
23. & Amad & 45 & SD & Sari Tani & Kp. Sawah Lega \\
24. & Cucu & 55 & SD & Sari Tani & Kp. Sawah Lega \\
25. & Acep & 36 & SD & Mekar Tani & Kp. Tegallega \\
26. & Iyang & 42 & Mekar Tani & Kp. Tegallega \\
27. & Ayi & 40 & Mekar Tani & Kp. Tegallega \\
28. & Ridwan & 42 & Kegallega \\
29. & Ai Ayida & 38 & Mekar Tani & Kp. Tegallega \\
30. & Imas & 38 & Kp. Tegallega \\
\hline
\end{tabular}

Sumber : Data Profil Kelompok Tani di Desa Tegallega.

Struktur Organisasi anggota kelompok tani ditentukan melalui kesepakatan bersama, atas dasar musyawarah bersama. Pendidikan anggota dari kelompok tani di Desa Tegallega sebagian besar terbilang masih sangat rendah, dengan berbekal Ijazah SD dan pengetahuan yang seadanya serta pengalaman yang sebelumnya melanjutkan dari prang tuanya.

\section{Deskriptif Hasil Penelitian}

Responden memberikan jawaban atas pernyataan tentang kepemimpinan dapat dilihat dari tabel 1. sebagai berikut:

Tabel 3. Statistika Deskriptif Variabel Kepemimpinan Responden.

\begin{tabular}{lc|c|c|c}
\hline & \multicolumn{3}{c}{ Descriptive Statistics } & \\
& N & \multicolumn{2}{c}{ Mean } & Std. Deviation \\
& Statistic & Statistic & Std. Error & Statistic \\
\hline X1.1 & 30 & 3.50 & .104 & .572 \\
X1.2 & 30 & 4.03 & .076 & .414 \\
X1.3 & 30 & 3.57 & .164 & .898 \\
X1.4 & 30 & 3.67 & .146 & .802 \\
Valid N (listwise) & 30 & & & \\
\hline
\end{tabular}

Sumber : Data Primer, 2019

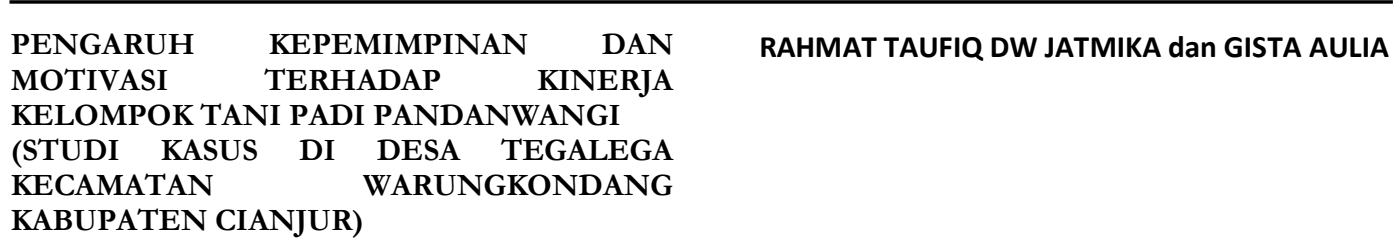


Dari tabel di atas menunjukan hasil dari responden variabel pendidikan X1.1 dengan pernyataan. "ketua kelompok tani kami adalah orang yang berwibawa". Dari jumlah responden sebanyak 30, dari tingkat rata rata statistic jawaban berjumlah 3,50 yang berarti bahwa nilai responden tersebut menjawab di kategori netral terhadap pernyataan yang sudah diajukan.

Tabel 4. Distribusi Frekuensi Jawaban Responden Terhadap X1.1

\begin{tabular}{lcc|c|c|c}
\hline \multicolumn{7}{c}{} & \multicolumn{5}{c}{ X1.1 } \\
\hline Valid & Frequency & Percent & Valid Percent & Cumulative Percent \\
\cline { 2 - 6 } & 2 & 1 & 3.3 & 3.3 & 3.3 \\
\cline { 2 - 6 } & 13 & 43.3 & 43.3 & 46.7 \\
\cline { 2 - 6 } & 4 & 16 & 53.3 & 53.3 & 100.0 \\
\hline & Total & 30 & 100.0 & 100.0 & \\
\hline
\end{tabular}

.Sumber : Data Primer, 2019.

Dari tabel diatas menunjukan hasil jawaban responden pada pernyataan yang sudah diajukan yaitu 1 reponden atau $3.3 \%$ menjawab tidak setuju, 13 responden atau $43.3 \%$ menjawab netral dan 16 responden atau $53.3 \%$ menjawab setuju. yang berarti X1.1 responden menjawab setuju dan terhadap pengaruh kepemimpinan ketua kelompok tani terhadap kelompok tani.
Dari tabel diatas menunjukan hasil dari responden variabel pendidikan X1.2 dengan pernyataan. "ketua kelompok senantiasa mau berbagi informasi, pengetahuan dengan kelompok tani" jumlah responden sebanyak 30, dari tingkat rata rata statistic jawaban berjumlah 4,03. yang berarti bahwa nilai responden tersebut menjawab di kategori setuju dan sangat setuju terhadap pertanyaan yang sudah diajukan.

Tabel 5. Distribusi Frekuensi Jawaban Responden Terhadap X1.2

\begin{tabular}{|c|c|c|c|c|c|}
\hline \multicolumn{6}{|c|}{$\mathrm{X} 1.2$} \\
\hline & & Frequency & Percent & Valid Percent & Cumulative Percent \\
\hline \multirow[t]{4}{*}{ Valid } & 3 & 2 & 6.7 & 6.7 & 6.7 \\
\hline & 4 & 25 & 83.3 & 83.3 & 90.0 \\
\hline & 5 & 3 & 10.0 & 10.0 & 100.0 \\
\hline & Total & 30 & 100.0 & 100.0 & \\
\hline
\end{tabular}

Sumber : Data Primer, 2019.

Dari tabel diatas menunjukan hasil jawaban responden pada pernyataan yang sudah diajukan yaitu 2 reponden atau $6.7 \%$ menjawab netral, 28 responden atau 93.3\% menjawab setuju dan sangat setuju. yang berarti X1.2 responden menjawab setuju dan terhadap pengaruh kepemimpinan ketua kelompok tani terhadap kelompok tani.

Dari tabel diatas menunjukan hasil dari responden variabel pendidikan X1.3 dengan pernyataan. "ketua kelompok dapat membantu petani dalam mengembangkan budidaya padi Pandanwangi" jumlah responden sebanyak 30, dari tingkat rata rata statistik jawaban berjumlah 3,57. yang berarti bahwa nilai responden tersebut menjawab di kategori setuju terhadap pertanyaan yang sudah diajukan.

Pada tabel frequency terdapat seberapa menjawab responden dari pernyataan yang sudah diajukan, dapat dilihat sebagai berikut :

\begin{tabular}{|c|c|c|}
\hline PENGARUH & KEPEMIMPINAN & DAN \\
\hline MOTIVASI & TERHADAP & KINERJA \\
\hline \multicolumn{3}{|c|}{ KELOMPOK TANI PADI PANDANWANGI } \\
\hline (STUDI & DESA & EGALEGA \\
\hline KECAMATAN & WARUNGK & ONDANG \\
\hline KABUPATEN CI & JJUR) & \\
\hline
\end{tabular}


Tabel 6. Frekuensi Jawaban Responden Terhadap X1.3.

\begin{tabular}{lcc|c|c|c}
\hline & \multicolumn{2}{c}{ X1.3 } & & \\
& & Frequency & Percent & Valid Percent & Cumulative Percent \\
\hline Valid & 2 & 5 & 16.7 & 16.7 & 16.7 \\
\cline { 2 - 6 } & 3 & 6 & 20.0 & 20.0 & 36.7 \\
\cline { 2 - 6 } & 4 & 53.3 & 53.3 & 90.0 \\
\cline { 2 - 6 } & 5 & 16 & 10.0 & 10.0 & 100.0 \\
\hline & Total & 30 & 100.0 & 100.0 & \\
\hline
\end{tabular}

Sumber : Data Primer, 2019.

Dari tabel diatas menunjukan hasil jawaban responden pada peryataan yang sudah diajukan yaitu 5 reponden atau $16.7 \%$ menjawab tidak setuju, 6 responden atau $20.0 \%$ menjawab netral dan 19 responden menjawab setuju dan sangat setuju. yang berarti X1.3 responden menjawab setuju dan sangat setuju terhadap pengaruh kepemimpinan ketua kelompok tani terhadap kelompok tani.

Dari tabel diatas menunjukan hasil dari responden variabel pendidikan X1.4 dengan pernyataan. "ketua kelompok tani kami adalah orang yang berpengalaman dalam budidaya padi Pandanwangi"? jumlah responden sebanyak 30, dari tingkat rata rata statistic jawaban berjumlah 3,67. yang berarti bahwa nilai responden tersebut menjawab di kategori setuju terhadap pertanyaan yang sudah diajukan.

Pada tabel frequency terdapat seberapa menjawab responden dari pernyataan yang sudah diajukan, dapat dilihat sebagai berikut :

Tabel 7. Distribusi Frekuensi Jawaban Responden Terhadap X1.4

\begin{tabular}{|c|c|c|c|c|c|}
\hline \multicolumn{6}{|c|}{ X1.4 } \\
\hline & & Frequency & Percent & Valid Percent & Cumulative Percent \\
\hline \multirow[t]{5}{*}{$\overline{\text { Valid }}$} & 2 & 3 & 10.0 & 10.0 & 10.0 \\
\hline & 3 & 7 & 23.3 & 23.3 & 33.3 \\
\hline & 4 & 17 & 56.7 & 56.7 & 90.0 \\
\hline & 5 & 3 & 10.0 & 10.0 & 100.0 \\
\hline & Total & 30 & 100.0 & 100.0 & \\
\hline
\end{tabular}

Sumber: Data Primer, 2019.

Dari tabel diatas menunjukan hasil jawaban responden pada peryataan yang sudah diajukan yaitu 3 reponden atau $10,0 \%$ menjawab tidak setuju, 7 responden atau $23.3 \%$ menjawab netral dan 20 responden atau $66.7 \%$ menjawab setuju dan sangat setuju. yang berarti X1.4 responden menjawab setuju dan sangat setuju terhadap pengaruh kepemimpinan ketua kelompok tani terhadap kelompok tani.

\section{Variabel Motivasi}

Responden memberikan jawaban terhadap pertanyaan tentang pengalaman, dapat dilihat pada tabel 4.6 sebagai berikut

PENGARUH
KEPEMIMPINAN
MOTIVASI DAN
TERHADAP
KELOMPOK TANI PADI PANDANWANGI
(STUDI KASUS DI DESA TEGALEGA
KECAMATAN
KABUPATEN CIANJUR)


Tabel 8. Statistika Deskriptif Variabel Motivasi Responden.

\begin{tabular}{lc|c|c|c} 
& & \multicolumn{2}{c}{ Descriptive Statistics } & Std. Deviation \\
& Statistic & Statistic & Std. Error & Statistic \\
\hline X2.1 & 30 & 3.93 & .106 & .583 \\
\hline X2.2 & 30 & 3.60 & .123 & .675 \\
\hline X2.3 & 30 & 3.80 & .121 & .664 \\
\hline X2.4 & 30 & 3.07 & .172 & .944 \\
\hline X2.5 & 30 & 3.07 & .159 & .868 \\
\hline Valid N (listwise) & 30 & & & \\
\hline
\end{tabular}

Sumber: Data Primer, 2019.

Dari tabel diatas menunjukan hasil dari responden variabel pengalaman X2.1 dengan pernyataan. "ketua kelompok menyediakan waktu yang baik untuk anggota kelompoknya"?jumlah responden sebanyak 30, dari tingkat rata rata statistik jawaban berjumlah 3.93. yang berarti bahwa nilai responden tersebut menjawab di kategori netral dan setuju terhadap pertanyaan yang sudah diajukan.

Pada tabel frekuensi terdapat seberapa menjawab responden dari pernyataan yang sudah diajukan, dapat dilihat sebagai berikut :

Tabel 9. Distribusi Frekuensi Jawaban Responden Terhadap X2.1.

\begin{tabular}{lcc|c|c|c}
\hline & \multicolumn{2}{c}{ X2.1 } & & \\
& & Frequency & Percent & Valid Percent & Cumulative Percent \\
\hline Valid & 2 & 1 & 3.3 & 3.3 & 3.3 \\
\cline { 2 - 6 } & 3 & 3 & 10.0 & 10.0 & 13.3 \\
\cline { 2 - 6 } & 23 & 76.7 & 76.7 & 90.0 \\
\cline { 2 - 6 } & 5 & 10.0 & 10.0 & 100.0 \\
\hline
\end{tabular}

Sumber: Data Primer, 2019.

Dari tabel diatas menunjukan hasil jawaban responden pada peryataan yang sudah diajukan yaitu 1 reponden atau $3.3 \%$ menjawab tidak setuju, 3 responden atau $10.0 \%$ menjawab netral dan 26 responden atau $86.7 \%$ menjawab setuju dan sangat setuju. yang berarti X2.1 responden menjawab setuju dan sangat setuju terhadap pengaruh motivasi kepada anggota kelompok tani dalam meningkatkan kinerja.

Dari tabel diatas menunjukan hasil dari responden dari variabel pengalaman
X2.2 dengan pernyataan "ketua kelompok tani selalu melakukan atau meminta pendapat kepada anggota " jumlah responden sebanyak 30, dari tingkat rata rata statistik jawaban berjumlah 3.60. yang berarti bahwa nilai responden tersebut menjawab di kategori netral dan setuju setuju terhadap pertanyaan yang sudah diajukan.

Pada tabel frekuensi terdapat seberapa menjawab responden dari pernyataan yang sudah diajukan, dapat dilihat sebagai berikut :

Tabel 10. Distribusi Frekuensi Jawaban Responden Terhadap X2.2.

\begin{tabular}{|c|c|c|c|c|c|}
\hline \multicolumn{6}{|c|}{$\mathrm{X} 2.2$} \\
\hline & & Frequency & Percent & Valid Percent & Cumulative Percent \\
\hline \multirow[t]{4}{*}{ Valid } & 2 & 3 & 10.0 & 10.0 & 10.0 \\
\hline & 3 & 6 & 20.0 & 20.0 & 30.0 \\
\hline & 4 & 21 & 70.0 & 70.0 & 100.0 \\
\hline & Total & 30 & 100.0 & 100.0 & \\
\hline
\end{tabular}

Sumber : Data Primer, 2019

PENGARUH KEPEMIMPINAN DAN
MOTIVASI TERHADAP KINERJA
KELOMPOK TANI PADI PANDANWANGI
(STUDI KASUS DI DESA TEGALEGA
KECAMATAN
KABUPATEN CIANJUR)


Dari tabel diatas menunjukan hasil jawaban responden pada peryataan yang sudah diajukan yaitu 3 reponden atau $10,0 \%$ menjawab tidak setuju, 6 responden atau $20.0 \%$ menjawab netral dan 21 responden atau $70.0 \%$ menjawab setuju. yang berarti X2.1 responden menjawab setuju dan sangat setuju terhadap pengaruh motivasi kepada anggota kelompok tani dalam meningkatkan kinerja.

Dari tabel diatas menunjukan hasil dari responden dari variabel pengalaman
X2.3 dengan pernyataan "ketua kelompok tani selalu memberikan arahan kepada anggotanya" jumlah responden sebanyak 30, dari tingkat rata rata statistik jawaban berjumlah 3.80. yang berarti bahwa nilai responden tersebut menjawab di kategori netral dan setuju terhadap pertanyaan yang sudah diajukan.

Pada tabel frekuensi terdapat seberapa menjawab responden dari pernyataan yang sudah diajukan, dapat dilihat sebagai berikut :

Tabel 11. Distribusi Frekuensi Jawaban Responden Terhadap X2.3

$\mathrm{X} 2.3$

\begin{tabular}{lcc|c|c|c} 
& & Frequency & Percent & Valid Percent & Cumulative Percent \\
\hline Valid & 2 & 6.7 & 6.7 & 6.7 \\
\cline { 2 - 6 } & 2 & 4 & 13.3 & 13.3 & 20.0 \\
\cline { 2 - 6 } & 22 & 73.3 & 73.3 & 93.3 \\
\hline 4 & 2 & 6.7 & 6.7 & 100.0 \\
\hline
\end{tabular}

Sumber : Data Primer, 2019.

Dari tabel diatas menunjukan hasil jawaban responden pada peryataan yang sudah diajukan yaitu 2 reponden atau $6.7 \%$ menjawab tidak setuju, 4 responden atau $13.3 \%$ menjawab netral dan 24 responden atau $79.7 \%$ menjawab setuju. yang berarti X2.2 responden menjawab setuju dan sangat setuju terhadap pengaruh motivasi kepada anggota kelompok tani dalam meningkatkan kinerja.

Dari tabel diatas menunjukan hasil dari responden dari variabel pengalaman X2.4 dengan pernyataan "ketua kelompok mengajak anggota untuk menanam padi Pandanwangi" jumlah responden sebanyak 30, dari tingkat rata rata statistik jawaban berjumlah 3.07 yang berarti bahwa nilai responden tersebut menjawab di kategori netral terhadap pertanyaan yang sudah diajukan.

Pada tabel frekuensi terdapat seberapa menjawab responden dari pernyataan yang sudah diajukan, dapat dilihat sebagai berikut :

Tabel 12. Distribusi Frekuensi Jawaban Responden Terhadap X2.4.

\begin{tabular}{lcc|c|c|c}
\hline & \multicolumn{5}{c}{ X2.4 } \\
& & Frequency & Percent & Valid Percent & Cumulative Percent \\
\hline Valid & 2 & 12 & 40.0 & 40.0 & 40.0 \\
\cline { 2 - 6 } & 3 & 4 & 13.3 & 13.3 & 53.3 \\
\cline { 2 - 6 } & 4 & 46.7 & 46.7 & 100.0 \\
\cline { 2 - 6 } & Total & 30 & 100.0 & 100.0 & \\
\hline
\end{tabular}

Sumber : Data Primer, 2019.

Dari tabel diatas menunjukan hasil jawaban responden pada peryataan yang sudah diajukan yaitu 12 reponden atau $40.0 \%$ menjawab tidak setuju, 4 responden atau $13.3 \%$ menjawab netral dan 14 responden atau $46.7 \%$ menjawab setuju. yang berarti X2.2 responden menjawab setuju dan sangat setuju terhadap pengaruh motivasi kepada anggota kelompok tani dalam meningkatkan kinerja.

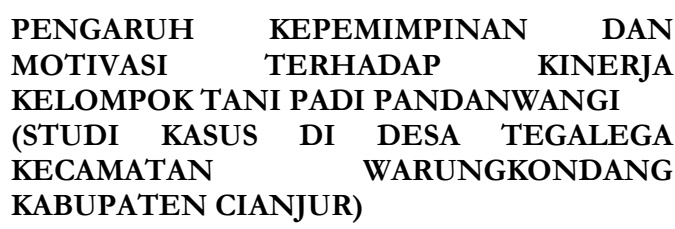


Dari tabel diatas menunjukan hasil dari responden dari variabel pengalaman X2.5 dengan pernyataan "sebagai anggota kelompok tani saya mengikuti anjutran ketua kelompok tani yang membudidayakan padi Pandanwangi’? jumlah responden sebanyak 30, dari tingkat rata rata statistik jawaban berjumlah 3.07. yang berarti bahwa nilai responden tersebut menjawab di kategori netral dan setuju setuju terhadap pertanyaan yang sudah diajukan.

Pada tabel frekuensi terdapat seberapa menjawab responden dari pernyataan yang sudah diajukan, dapat dilihat sebagai berikut :

Tabel 13. Distribusi Frekuensi Jawaban Responden Terhadap X2.5.

\begin{tabular}{lcc|cc|c}
\hline & & \multicolumn{3}{c}{ X2.5 } & \\
& & Frequency & Percent & Valid Percent & Cumulative Percent \\
\hline Valid & 2 & 10 & 33.3 & 33.3 & 33.3 \\
\cline { 2 - 6 } & 3 & 8 & 26.7 & 26.7 & 60.0 \\
\cline { 2 - 6 } & 12 & 40.0 & 40.0 & 100.0 \\
\cline { 2 - 6 } & Total & 30 & 100.0 & 100.0 & \\
\hline
\end{tabular}

Sumber : Data Primer, 2019.

Dari tabel diatas menunjukan hasil jawaban responden pada peryataan yang sudah diajukan yaitu 10 reponden atau $33.5 \%$ menjawab tidak setuju, 8 responden atau $26.7 \%$ menjawab netral dan 12 responden atau 40.0\% menjawab setuju. yang berarti X2.5 responden menjawab setuju dan terhadap pengaruh motivasi kepada anggota kelompok tani dalam meningkatkan kinerja.

Variabel Kinerja

Responden memberikan jawaban terhadap pertanyaan tentang pengalaman, dapat dilihat pada tabel sebagai berikut:

Tabel 14. Statistika Deskriptif Variabel Motivasi Responden.

\begin{tabular}{lc|c|c|c} 
& & \multicolumn{2}{c}{ Descriptive Statistics } & Std. Deviation \\
& Statistic & Statistic & Std. Error & Statistic \\
\hline Y1.1 & 30 & 3.43 & .157 & .858 \\
\hline Y1.2 & 30 & 3.17 & .097 & .531 \\
\hline Y1.3 & 30 & 2.90 & .130 & .712 \\
\hline Y1.4 & 30 & 3.00 & .117 & .643 \\
\hline Y1.5 & 30 & 3.83 & .128 & .699 \\
\hline Valid N (listwise) & 30 & & & \\
\hline
\end{tabular}

Sumber : Data Primer, 2019.

Dari tabel diatas menunjukan hasil dari responden variabel pendidikan Y1.1 dengan pernyataan. "Sebagai anggota kelompok tani saya mengikuti anjuran ketua kelompok tani menanam padi Pandanwangi. Dari jumlah responden sebanyak 30, dari tingkat rata rata statistik jawaban berjumlah 3,43 yang berarti bahwa nilai responden tersebut menjawab di kategori netral dan setuju terhadap pernyataan yang sudah diajukan.

Pada tabel frekuensi terdapat seberapa menjawab responden dari pernyataan yang sudah diajukan, dapat dilihat sebagai berikut :

$\begin{array}{llr}\text { PENGARUH } & \text { KEPEMIMPINAN } & \text { DAN } \\ \text { MOTIVASI } & \text { TERHADAP } & \text { KINERJA } \\ \text { KELOMPOK TANI PADI PANDANWANGI } & \text { PANANA } \\ \text { (STUDI KASUS } & \text { DI } \text { DESA TEGALEGA } \\ \text { KECAMATAN } & \text { WARUNGKONDANG } \\ \text { KABUPATEN CIANJUR) }\end{array}$


Tabel 15. Distribusi Frekuensi Jawaban Responden Terhadap Y1.1.

\begin{tabular}{|c|c|c|c|c|c|}
\hline \multicolumn{6}{|c|}{ Y1.1 } \\
\hline & & Frequency & Percent & Valid Percent & Cumulative Percent \\
\hline \multirow[t]{5}{*}{ Valid } & 2 & 5 & 16.7 & 16.7 & 16.7 \\
\hline & 3 & 9 & 30.0 & 30.0 & 46.7 \\
\hline & 4 & 14 & 46.7 & 46.7 & 93.3 \\
\hline & 5 & 2 & 6.7 & 6.7 & 100.0 \\
\hline & Total & 30 & 100.0 & 100.0 & \\
\hline
\end{tabular}

Sumber : Data Primer, 2019.

Dari tabel diatas menunjukan hasil jawaban responden pada peryataan yang sudah diajukan yaitu 5 reponden atau $16.7 \%$ menjawab tidak setuju, 9 responden atau $30.0 \%$ menjawab netral dan 16 responden atau $46.7 \%$ menjawab setuju. yang berarti Y1.1 responden menjawab setuju dan sangat setuju terhadap pengaruh kinerja kelompok tani.

Dari tabel diatas menunjukan hasil dari responden dari variabel pengalaman Y1.2 dengan pernyataan "menurut pengamatan saya, banyak anggota kelompok tani yang membudidayakan kelompok tani” jumlah responden sebanyak 30, dari tingkat rata rata statistik jawaban berjumlah 3.17. yang berarti bahwa nilai responden tersebut menjawab di kategori netral dan setuju terhadap pertanyaan yang sudah diajukan.

Pada tabel frekuensi terdapat seberapa menjawab responden dari pernyataan yang sudah diajukan, dapat dilihat sebagai berikut :

Tabel 16. Distribusi Frekuensi Jawaban Responden Terhadap Y1.2.

\begin{tabular}{ll|r|r|r|r}
\hline & & \multicolumn{2}{c}{ Y1.2 } & & \\
& & Frequency & Percent & Valid Percent & Cumulative Percent \\
\hline Valid & 2 & 2 & 6.7 & 6.7 & 6.7 \\
\cline { 2 - 7 } & & 21 & 70.0 & 70.0 & 76.7 \\
\cline { 2 - 7 } & & 7 & 23.3 & 23.3 & 100.0 \\
\cline { 2 - 7 } & Total & 30 & 100.0 & 100.0 & \\
\hline
\end{tabular}

Sumber: Data Primer, 2019.

Dari tabel diatas menunjukan hasil jawaban responden pada pernyataan yang sudah diajukan yaitu 2 reponden atau $6.7 \%$ menjawab tidak setuju, 21 responden atau $70.0 \%$ menjawab netral dan 7 responden atau $23.3 \%$ menjawab setuju. yang berarti Y1.2 responden menjawab setuju dan terhadap pengaruh kinerja kelompok tani.

Dari tabel diatas menunjukan hasil dari responden dari variabel pengalaman Y1.3 dengan pernyataan "menurut saya, budidaya padi Pandanwangi adalah menguntungkan" jumlah responden sebanyak 30, dari tingkat rata rata statistik jawaban berjumlah 2.90. yang berarti bahwa nilai responden tersebut menjawab di kategori tidak setuju terhadap pertanyaan yang sudah diajukan.

Pada tabel frekuensi terdapat seberapa menjawab responden dari pernyataan yang sudah diajukan, dapat dilihat sebagai berikut :

Tabel 17. Distribusi Frekuensi Jawaban Responden Terhadap Y1.3.

\begin{tabular}{|c|c|c|c|c|c|}
\hline & & & Y1.3 & & \\
\hline & & Frequency & Percent & Valid Percent & Cumulative Percent \\
\hline Valid & 2 & 9 & 30.0 & 30.0 & 30.0 \\
\hline & 3 & 15 & 50.0 & 50.0 & 80.0 \\
\hline & 4 & 6 & 20.0 & 20.0 & 100.0 \\
\hline & Total & 30 & 100.0 & 100.0 & \\
\hline
\end{tabular}

Sumber : Data Primer, 2019.

PENGARUH KEPEMIMPINAN DAN
MOTIVASI TERHADAP KINERJA
KELOMPOK TANI PADI PANDANWANGI
(STUDI KASUS DI DESA TEGALEGA
KECAMATAN
KABUPATEN CIANJUR)


Karakteristik responden akan dibahas berdasarkan variabel : Umur, jenis kelamin, pendidikan terakhir, Usia, luas lahan. Berikut adalah penjelasan dari ketiga variabel tersebut:
1. Umur

Petani padi Pandanwangi di Desa Tegallega Kecamatan Warungkondang. Jumlah responden adalah sebanyak 30 orang umur responden berkisaran 22-65 tahun.

Tabel 20. Karakteristik Usia Responden.

\begin{tabular}{clcc}
\hline No & \multicolumn{1}{c}{ Umur } & Presentase & Jumlah Orang \\
\hline 1 & $<19$ Tahun & & \\
2 & $19-59$ Tahun & $90 \%$ & 27 \\
3 & $>59$ Tahun & $10 \%$ & 3 \\
& Total & $100 \%$ & 30 \\
\hline
\end{tabular}

Sumber : data primer, 2019 (diolah).

Pada gambar diatas dapat dilihat bahwa mayoritas responden dalam penelitian ini 19-59 tahun sebanyak 27 orang dengan presentase $90 \%$. Dan umur lebih dari 59 tahun sebanyak 3 orang dengan presentase 10\%. Maka dapat disimpulkan bahwa mayoritas umur petani padi Pandanwangi di desa Tegallega kurang dati 59 tahun.

\section{Jenis Kelamin}

Tabel 21. Karakteristik Jenis Kelamin Responden.

\begin{tabular}{|c|l|c|c|}
\hline No & \multicolumn{1}{|c|}{ Jenis Kelamin } & Presentase & Jumlah Orang \\
\hline 1 & Laki-Laki & $83 \%$ & 25 \\
\hline 2 & Perempuan & $17 \%$ & 5 \\
\hline & Total & $100 \%$ & 30 \\
\hline
\end{tabular}

Sumber: Data primer 2019 (diolah).

Berdasarkan presentasi dari hasil olahan data diatas, responden didominasi oleh laki-laki, mengingat bahwa lebih bertanggung jawab dalam hal pekerjaan sehingga $83 \%$ responden berjenis kelamin laki-laki. Hal ini menunjukan bahwa kegiatan usahatani, laki-laki lebih banyak berperan. Laki-laki juga dianggap sebagai pemimpin sehingga dalam usahatani laki-laki dianggap lebih berperan dalam merencanakan dan menjalankan kegiatan usahatani (Darwis, 2010).

\section{Tingkat Pendidikan}

Menurut Suhardjo (2007), tingkat pendidikan adalah tahapan pendidikan yang ditetapkan berdasarkan tingkat perkembangan peserta didik, tujuan yang akan dicapai dan kemauan yang dikembangkan. Tingkat pendidikan seseorang berpengaruh terhadap perubahan sikap dan prilaku. Tingkat pendidikan yang lebih tinggi akan memudahkan seseorang untuk menyerap informasi dan dapat diterapkan dalam prilaku dan gaya hidup sehari-hari. Berikut adalah karakteristik responden berdasarkan tingkat pendidikan:

Tabel 22. Karakteristik Tingkat Pendidikan Responden.

\begin{tabular}{clcc}
\hline No & \multicolumn{1}{c}{ Tingkat Pendidikan } & Presentase & Jumlah Orang \\
\hline 1 & Tidak Tamat SD & $27 \%$ & 8 \\
2 & SD & $63 \%$ & 19 \\
3 & SMP/Sederajat & & 3 \\
4 & SMA/Sederajat & $10 \%$ & 30 \\
5 & Perguruan Tinggi & & \\
\multicolumn{2}{c}{ Total } & $100 \%$ & \\
\hline
\end{tabular}

Sumber : Data primer, 2019 (diolah)

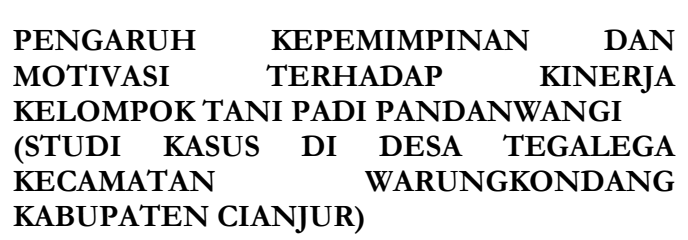


Berdasarkan presentase tingkat pendidikan responden masih sangat rendah, tidak tamat sekolah dasar (SD) sebanyak 8 responden, lulusan Sekolah dasar (SD) paling dominan yaitu sebanyak 19 responden dan lulusan SMA 3 responden. Dengan melihat tingkat pendidikan yang masih rendah maka pendidikan informal merupakan salah satu langkah yang tepat.

Tabel 23. karakteristik luas lahan responden.

\begin{tabular}{cccc}
\hline No & Luas Lahan & Presentase & Jumlah Orang \\
\hline 1 & $<0.5$ ha & $60 \%$ & 18 \\
2 & $0.5-1$ ha & $37 \%$ & 11 \\
3 & $1-2$ ha & $3 \%$ & 1 \\
4 & $>2$ ha & & 30 \\
\hline
\end{tabular}

Sumber : Data primer 2019 (diolah).

Berdasarkan presentase luas lahan yang responden garap, responden yang menggarap lahan luas $<0.5$ ha sebanyak 18 orang responden, jumlah lahan garapan luas $0.5-1$ ha sebanyak 11 orang dan lahan garapan luas $>2$ ha sebanyak responden.

\section{Uji Validitas}

Menurut Ghozali (2006) Uji validitas digunakan untuk mengukur sah atau valid tidaknya suatu kuesioner. Suatu kuesioner dikatakan valid jika pertanyaan pada kuesioner mampu untuk mengungkapkan sesuatu yang akan diukur oleh kuesioner tersebut. Untuk mengukur validitas yaitu dengan melakukan korelasi antara skor butir pertanyaan dengan total skor konstruk atau variabel. Sedangkan

\section{Luas Lahan}

Menurut Mutma'inah Rika (2014) luas lahan merupakan salah satu faktor pendukung dalam meningkatkan produktifitas hasil tani yang diperoleh. Karena semakin luas lahan yang dimiliki maka akan semakin tinggi pula produksi yang dihasilkan. Berikut adalah karakteristik responden berdasarkan luas lahan : untuk mengetahui skor masing masing item peryataan valid atau tidak, maka ditetapkan kriteria statistik sebagai

a. Jika $\mathrm{r}$ hitung $>\mathrm{r}$ tabel dan bernilai positif, maka variabel tersebut valid.

b. Jika $\mathrm{r}$ hitung $<\mathrm{r}$ tabel, maka variabel tersebut tidak valid.

Hasil pengujian instrumen penelitian yang digunakan peneliti dengan membandingkan nilai Corrected itemTotal correlation dengan nilai $\mathrm{r}_{\text {tabel }}$ menggunakan rumus $\mathrm{df}=\mathrm{n}-2$ dengan Alpha $\alpha 0,005$, atau $\mathrm{df}=30-2=28$, maka diperoleh nilai pada $\mathrm{r}_{\text {tabel }}=0,4629$.

Berdasarkan uji validitas di atas hail dari $\mathrm{r}$ tabel dapat dilihat dari tabel berikut ini: berikut: pengujian X1 di hasil dari nilai $r$ hitung $>$

Tabel 24. Hasil Uji Validitas $\mathrm{X}_{1}$.

\begin{tabular}{cccc}
\hline Item & Corrected Item- Total Correlation & R tabel & Hasil Uji Validitas \\
\hline X1.1 & 0.433 & 0,4629 & Tidak Valid \\
X1.2 & 0.534 & 0,4629 & Valid \\
X1.3 & 0.849 & 0,4629 & Valid \\
X1.4 & 0.809 & 0,4629 & Valid \\
\hline
\end{tabular}

Sumber : Data Primer, 2019.

Pada tabel diatas menunjukan bahwa hasil nilai atau jumlah X1.1 sebesar 0433, menunjukan bahwa nilai $r_{\text {hitung }}$ lebih besar dari $>r_{\text {tabel }}$ 0,4629. Sehingga dapat dikatakan bahwa hasil dari X1.1 dinyatakan tidak valid. Pada tabel diatas

\begin{tabular}{|c|c|c|}
\hline PENGARUH & KEPEMIMPINAN & RAHMAT TAUFIQ DW JATMIKA dan GISTA AULIA \\
\hline MOTIVASI & TERHADAP & \\
\hline \multicolumn{3}{|c|}{ KELOMPOK TANI PADI PANDANWANGI } \\
\hline (STUDI KASUS & DI DESA TEGALEGA & \\
\hline KECAMATAN & WARUNGKONDANG & \\
\hline
\end{tabular}


X1.3 sebesar 0,849, menunjukan bahwa nilai $\mathrm{r}_{\text {hitung }}$ lebih besar dari $>\mathrm{r}_{\text {tabel }} \quad 0,4629$. Sehingga dapat dikatakan bahwa hasil dari X1.3 dinyatakan valid. Pada tabel diatas menunjukan bahwa hasil nilai atau jumlah X1.4 sebesar 0,809, menunjukan bahwa nilai rhitung lebih besar dari $>\mathrm{r}_{\text {tabel }} 0,4629$.
Sehingga dapat dikatakan bahwa hasil dari $\mathrm{X} 1.4$ dinyatakan valid.

\section{Uji Validitas Motivasi X2}

Berdasarkan uji validitas di atas hail dari pengujian $\mathrm{X} 1$ di hasil dari nilai $\mathrm{r}$ hitung $>\mathrm{r}$ tabel dapat dilihat dari tabel berikut ini :

Tabel 25. Uji Validitas $\mathrm{X}_{2}$

\begin{tabular}{lccc}
\hline Item & Corrected Item- Total Correlation & R tabel & Hasil Uji Validitas \\
\hline X2.1 & 0.733 & 0,4629 & Valid \\
X2.2 & 0.712 & 0,4629 & Valid \\
X2.3 & 0.740 & 0,4629 & Valid \\
X2.4 & 0.818 & 0,4629 & Valid \\
X2.5 & 0.857 & 0,4629 & Valid \\
\hline
\end{tabular}

Sumber : Data Primer, 2019.

Pada tabel diatas menunjukan bahwa hasil nilai atau jumlah X2.1 sebesar 0,733, menunjukan bahwa nilai $\mathrm{r}_{\text {hitung }}$ lebih besar dari $>r_{\text {tabel }}$ 0,4629. Sehingga dapat dikatakan bahwa hasil dari X2.1 dinyatakan valid. Pada tabel diatas menunjukan bahwa hasil nilai atau jumlah X2.2 sebesar 0,712, menunjukan bahwa nilai $r_{\text {hitung }}$ lebih besar dari $>r_{\text {tabel }} 0,4629$. Sehingga dapat dikatakan bahwa hasil dari X2.2 dinyatakan valid. Pada tabel diatas menunjukan bahwa hasil nilai atau jumlah X2.3 sebesar 0,740, menunjukan bahwa nilai $r_{\text {hitung }}$ lebih besar dari $>r_{\text {tabel }} 0,4629$. Sehingga dapat dikatakan bahwa hasil dari X1.3 dinyatakan valid. Pada tabel diatas menunjukan bahwa hasil nilai atau jumlah X2.4 sebesar 0,818, menunjukan bahwa nilai $\mathrm{r}_{\text {hitung }}$ lebih besar dari $>\mathrm{r}_{\text {tabel }} \quad 0,4629$. Sehingga dapat dikatakan bahwa hasil dari X2.4 dinyatakan valid. Pada tabel diatas menunjukan bahwa hasil nilai atau jumlah X2.5 sebesar 0,857, menunjukan bahwa nilai $r_{\text {hitung }}$ lebih besar dari $>r_{\text {tabel }} 0,4629$. Sehingga dapat dikatakan bahwa hasil dari X2.4 dinyatakan valid.

\section{Uji Validitas Kinerja Y}

Berdasarkan uji validitas di atas hail dari pengujian X1 di hasil dari nilai $r$ hitung $>\mathrm{r}$ tabel dapat dilihat dari tabel berikut ini :

Tabel 26. Uji Validitas kinerja (Y).

\begin{tabular}{cccc}
\hline Item & Corrected Item- Total Correlation & R tabel & Hasil Uji Validitas \\
\hline Y1.1 & 0.818 & 0,4629 & Valid \\
Y1.2 & 0.328 & 0,4629 & Tidak Valid \\
Y1.3 & 0.794 & 0,4629 & Valid \\
Y1.4 & 0.703 & 0,4629 & Valid \\
Y1.5 & 0.782 & 0,4629 & Valid \\
\hline
\end{tabular}

Sumber : Data Primer, 2019.

Pada tabel diatas menunjukan bahwa hasil nilai atau jumlah Y1.1 sebesar 0,818 , menunjukan bahwa nilai $\mathbf{r}_{\text {hitung }}$ lebih besar dari $>r_{\text {tabel }}$ 0,4629. Sehingga dapat dikatakan bahwa hasil dari Y1.2 dinyatakan valid. Pada tabel diatas menunjukan bahwa hasil nilai atau jumlah Y1.3 sebesar 0,328, menunjukan bahwa nilai $r_{\text {hitung }}$ lebih besar dari $>r_{\text {tabel }} 0,4629$.
Sehingga dapat dikatakan bahwa hasil dari Y1.2 dinyatakan tidak valid. Pada tabel diatas menunjukan bahwa hasil nilai atau jumlah Y1.3 sebesar 0,794, menunjukan bahwa nilai $r_{\text {hitung }}$ lebih besar dari $>r_{\text {tabel }}$ 0,4629. Sehingga dapat dikatakan bahwa hasil dari Y1.3 dinyatakan valid. Pada tabel diatas menunjukan bahwa hasil nilai atau jumlah Y1.4 sebesar 0,703,

\begin{tabular}{|c|c|c|}
\hline PENGARUH & KEPEMIMPINAN & DAN \\
\hline MOTIVASI & TERHADAP & KINERJA \\
\hline \multicolumn{3}{|c|}{ KELOMPOK TANI PADI PANDANWANGI } \\
\hline (STUDI & DESA & EGALEGA \\
\hline KECAMATAN & WARUNGK & ONDANG \\
\hline
\end{tabular}


menunjukan bahwa nilai $\mathrm{r}_{\text {hitung }}$ lebih besar dari $>r_{\text {tabel }}$ 0,4629. Sehingga dapat dikatakan bahwa hasil dari Y1.5 dinyatakan valid. Pada tabel diatas menunjukan bahwa hasil nilai atau jumlah X1.5 sebesar 0,784, menunjukan bahwa

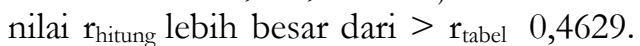
Sehingga dapat dikatakan bahwa hasil dari X2.4 dinyatakan valid.

\section{Uji Reliabilitas}

Menurut Purwono (2016) uji reliabilitas adalah alat untuk mengukur suatu kuesioner yang mempunyai indikator dari variabel atau konstruk. Suatu kuesioner dinyatakan reliabel atau handal jika jawaban seseorang terhadap pernyataan adalah konsisten atau stabil

Tabel 27. Uji Reliabelitas $\mathrm{X}_{1}$ dari waktu ke waktu. Uji reliabilitas dapat dilakukan dengan menggunakan bantuan program SPSS (statistical program for sosial science), yang akan memberikan fasilitas untuk mengukur reliabilitas dengan uji statistik Cronbach Alpha (a). Suatu konstruk atau variabel dikatakan reliabel jika memberikan nilai Cronbanch Alpha $>0,60$.

\section{Uji Reliabel $\mathbf{X}_{1}$}

Uji dilakukan dengan cara membandingkan angka crobach alpha dengan ketentuan nilai crombach alpha minimal adalah 0.6. Artinya nilai crombach alpha yang didapatkan dari hasil perhitungan spss lebih besar dari 0.6 maka kuisioner reliabel.

\section{Reliability Statistics}

\begin{tabular}{c|c|c} 
Cronbach's Alpha & Cronbach's Alpha Based on Standardized Items & N of Items \\
\hline .713 & .731 & 4 \\
\hline
\end{tabular}

Sumber : Data Primer, 2019.

Pada kuesioner variable $\mathrm{X}_{1}$ menunjukan hasil cronbach's Alpha 0,713 pada tiap-tiap pertanyaan. Bahwa hasil menunjukan lebih besar dari $>0,6$ dari

Tabel 28. Uji Reliabelitas $\mathrm{X}_{2}$ jumlah item pada pertanyaan sebanyak 4 point. Dengan hasil tersebut maka kuesioner sudah bisa dikatakan reliable atau terpercaya.

\begin{tabular}{c|ccc}
\hline & \multicolumn{2}{c}{ Reliability Statistics } & \\
Cronbach's Alpha & Cronbach's Alpha Based on Standardized Items & N of Items \\
\hline .856 & .864 & 5 \\
\hline
\end{tabular}

Sumber: Data Primer, 2019.

Pada kuesioner variable $\mathrm{X}_{2}$ menunjukan hasil cronbach's Alpha 0,856 pada tiap-tiap pertanyaan. Bahwa hasil menunjukan lebih besar dari $>0,6$ dari jumlah item pada pertanyaan sebanyak 4 point. Dengan hasil tersebut maka kuesioner sudah bisa dikatakan reliable atau terpercaya.

\section{Uji Reliabel Y}

\section{Uji Reliabilitas Kinerja (Y)}

Pada kuesioner variable Y menunjukan hasil cronbach's Alpha 0,778 pada tiap tiap pertanyaan. Bahwa hasil menunjukan lebih besar dari $>0,6$ dari jumlah item pada pertanyaan sebanyak 6 point. Dengan hasil tersebut maka kuesioner sudah bisa dikatakan reliable atau terpercaya. Sebagaimana dapat dilihat dalam tabel 4.8 di bawah ini :

Tabel 29. Uji Reliabel Y.

\begin{tabular}{r|c}
\hline & Reliability Statistics \\
Cronbach's Alpha & N of Items \\
\hline .778 & 6 \\
\hline
\end{tabular}

Sumber: Data Primer, 2019.

\begin{tabular}{l}
\hline PENGARUH \\
KEPEMIMPINAN \\
MOTIVASI DAN \\
KELOMPOK TANI PADI PANDANWANGI \\
(STUDI KASUS DI DESA TEGALEGA \\
KECAMATAN \\
KABUPATEN CIANJUR)
\end{tabular}




\section{Hasil Analisis Data Penelitian}

Metode analisis data dalam penelitian ini menggunakan analisis regresi linier berganda. Analisis regresi linier berganda digunakan untuk mengetahui

Tabel 30. Uji Analisis Regresi Berganda. bagaimana pengaruh karakteristik petani terhadap terhadap pengaruh kepemimpinan dan motivasi terhadap kineja.

\begin{tabular}{|c|c|c|c|c|c|c|}
\hline \multicolumn{7}{|c|}{ Coefficients $^{\mathrm{a}}$} \\
\hline \multirow{2}{*}{\multicolumn{2}{|c|}{ Model }} & \multicolumn{2}{|c|}{ Unstandardized Coefficients } & \multirow{2}{*}{$\begin{array}{c}\text { Standardized Coefficients } \\
\text { Beta }\end{array}$} & \multirow[b]{2}{*}{ t } & \multirow[b]{2}{*}{ Sig. } \\
\hline & & B & Std. Error & & & \\
\hline 1 & (Constant) & .510 & .404 & & 1.262 & .218 \\
\hline & $\mathrm{X} 1$ & .477 & .174 & .499 & 2.740 & .011 \\
\hline & $\mathrm{X} 2$ & .285 & .147 & .354 & 1.943 & .063 \\
\hline
\end{tabular}

a. Dependent Variable: Y

Sumber : Data Primer, 2019.

Berdasarkan hasil dari olahan SPSS

25 maka dipeoleh hasil persamaan regresi sebagai berikut :

$$
\mathrm{Y}=0,510+0,477 \mathrm{X}_{1}+0,285 \mathrm{X}_{2}+\mathrm{e}
$$

Keterangan :

$\mathrm{Y}$ : Kinerja

$\mathrm{X}_{1}$ : Pengaruh kepemimpinan

$\mathrm{X}_{2}$ : Motivasi

Dari hasil analisis diatas maka diperoleh nilai variabel kinerja $\mathrm{Y}$, dengan nilai Constanta positif 0,510. Variabel pengaruh kepemimpinan X1 bernilai positif 0,477 variabel motivasi $\mathrm{X} 2$ bernilai

Tabel 31. Uji T. positif 0,285 . Hal ini menunjukan bahwa semua variabel kepemimpinan dan motivasi secara parsial dan simultan atau bersama-sama mempunyai pengaruh yang bernilai positif terhadap kinerja.

\section{Uji T}

Uji $\mathrm{t}$ bertujuan untuk mengetahui variabel bebas yang berpengaruh terhadap variabel terikat secara satu variabel, dari hasil data yang dianalisis maka diperoleh hasil uji t pada tabel sebagai berikut:

\begin{tabular}{|c|c|c|c|c|c|c|}
\hline \multicolumn{7}{|c|}{ Coefficients $^{a}$} \\
\hline \multirow{2}{*}{\multicolumn{2}{|c|}{ Model }} & \multicolumn{2}{|c|}{ Unstandardized Coefficients } & \multirow{2}{*}{$\begin{array}{c}\text { Standardized Coefficients } \\
\text { Beta }\end{array}$} & \multirow[b]{2}{*}{$\mathbf{t}$} & \multirow[b]{2}{*}{ Sig. } \\
\hline & & $\mathrm{B}$ & Std. Error & & & \\
\hline 1 & (Constant) & .510 & .404 & & 1.262 & .218 \\
\hline & $\mathrm{X} 1$ & .477 & .174 & .499 & 2.740 & .011 \\
\hline & $\mathrm{X} 2$ & .285 & .147 & .354 & 1.943 & .063 \\
\hline
\end{tabular}

a. Dependent Variable: $\mathrm{Y}$

Sumber : Data Primer, 2019

$\mathrm{T}$ tabel $=\mathrm{t}(\mathrm{a} / 2: \mathrm{n}-\mathrm{k}-1): 0,10 / 2: 30-2-1=1.70329$.

a. Variabel kepemimpinan

Berdasarkan hasil uji $t$ untuk variabel $\mathrm{X}_{1}$ (kepemimpinan) dapat diperoleh nilai t hitung 2.740 dengan nilai signifikan 0,011 dengan menggunakan tingkat kepercayaan 0,10 dengan demikian ada pengaruh yang signifikan dari variabel kepemimpinan $\left(\mathrm{X}_{1}\right)$ terhadap kinerja $(\mathrm{Y})$.

b. Variabel Motivasi
Berdasarkan hasil uji $t$ untuk variabel $\mathrm{X}_{2}$ (motivasi) dapat diperoleh nilai t hitung 1.943 dengan nilai signifikan 0,063 dengan menggunakan tingkat kepercayaan 0,10 dengan demikian ada pengaruh yang signifikan dari variabel motivasi $\left(\mathrm{X}_{2}\right)$ terhadap kinerja.

Dapat disimpulkan bahwa variabel kepemimpinan dan motivasi berpengaruh terhadap kinerja dengan rincian pernyataan X1.1 “ ketua kelompok tani

PENGARUH KEPEMIMPINAN DAN
MOTIVASI TERHADAP KINERJA
KELOMPOK TANI PADI PANDANWANGI
(STUDI KASUS DI DESA TEGALEGA
KECAMATAN
KABUPATEN CIANJUR)


kami adalah orang yang berwibawa" X1.2 " ketua kelompok senantiasa mau berbagi informasi, pengetahuan dengan kelompok tani" X1.3 "ketua kelompok dapat membantu petani dalam mengembangkan budidaya padi Pandanwangi" X1.4 " ketua kelompok tani kami orang yang berpengalaman dalam budidaya padi Pandanwangi". Dari semua pernyataan tersebut bahwa jawaban responden dikategorikan setuju dan sangat setuju. Jadi dari hasil uji t menyatakan bahwa yang paling berpengaruh yang signifikan terhadap kinerja adalah $\mathrm{X}_{1}$ kepemimpinan.

\section{Uji F}

Menurut Sudrajat (2011) dalam Anwar (2015) Uji F digunakan untuk melihat apakah model regresi yang dianalisis memiliki tingkat kelayakan model yang tinggi yaitu variabel- variabel yang digunakan model regresi. Untuk mengetahui penjelasan kenyataan yang dianalisis, dengan kriteria sebagai berikut :

1. Jika nilai probabilitas $<0,05$ maka model dihasilkan layak

2. Jika nilai probabilitas $>0,05$ maka model yang dihasilkan tidak layak

Untuk mengetahui apakah dua variabel bebas $\left(\mathrm{X}_{1}, \mathrm{X}_{2}\right)$ memiliki tingkat kelayakan model terhadp variabel terikat (Y). Berdasarkan tebel maka dapar diperoleh hasil:

Tebel 32. Uji Kelayakan Model dengan Uji F.

\begin{tabular}{|c|c|c|c|c|c|c|}
\hline \multicolumn{7}{|c|}{ ANOVA $^{a}$} \\
\hline Model & & Sum of Squares & df & Mean Square & $\mathbf{F}$ & Sig. \\
\hline \multirow[t]{3}{*}{1} & Regression & 4.496 & 2 & 2.248 & 25.176 & $.000^{\mathrm{b}}$ \\
\hline & Residual & 2.411 & 27 & .089 & & \\
\hline & Total & 6.907 & 29 & & & \\
\hline
\end{tabular}

a. Dependent Variable: Y

b. Predictors: (Constant), X2, X1

Sumber : Analisis data primer, 2019

F tabel : F $(\mathrm{k}: \mathrm{n}-\mathrm{k})=(2: 30-2=28)=3.34$

Hasil perhitungan statistik menunjukan nilai $\mathrm{F}$ hitung $>\mathrm{F}$ tabel 25.176 dengan nilai signifikan $0,000<$ 0,05. Dengen demikian, menunjukan bahwa ada pengaruh secara simultan atau secara bersama serta signifikan dari variabel kepemimpinan $\left(\mathrm{X}_{1}\right)$ motivasi $\left(\mathrm{X}_{2}\right)$ terhadap kinerja (Y).

Dari hasil penelitian, dapat diamati bahwa kepemimpinan ketua kelompok erat hubungan dengan motivasi terhadap kinerja kelompok tani di Desa Tegallega Kecamatan Warungkondang. Hail penelitian ini sangat selaras dengan pendapat Bass dalam Unang (2015) yang menyatakan bahwa pemimpin (ketua kelompok) adalah agen perubahan seseorang yang akan lebih mempengaruhi. Kepemimpinan merupakan suatu interaksi antara dua orang atau lebih anggota yang sering mencakup penyusunan stuktur atau pengubahan struktur dari situasi dan persepsi dan harapan para anggota.
Kepemimpinan akan muncul ketika satu anggota kelompok (ketua kelompok) dapat memotivasi pada anggota kelompoknya.

Menurut Zakkariya (2010), Fungsi kelompok tani akan berjalan dengan baik apabila pemimpin / ketua kelompok tani mampu menggerakan anggota kelompok tani untuk melakukan sesuatu untuk mencapai tujuan. Dalam menggerakan anggota, kepemimpinan kelompok tani sangat menentukan sikap anggota kelompok terhadap perintah maupun informasi yang diberikan.

Kepemimpinan (ketua kelompok tani) di Desa Tegallega sangat berpengaruh terhadap kinerja anggota kelompok tani, ketua kelompok di Desa Tegallega sangat aktif selalu membantu anggota nya dalam membudidayakan dan pemeliharaan padi Pandanwangi. Ketua kelompok tani selalu mengajak anggotanya mengikuti kegiatan

PENGARUH KEPEMIMPINAN DAN
MOTIVASI TERHADAP KINERJA
KELOMPOK TANI PADI PANDANWANGI
(STUDI KASUS DI DESA TEGALEGA
KECAMATAN
KABUPATEN CIANJUR)


penyuluhan dan selalu memberikan arahan kepada anggotanya.

Anggota kelompok tani selalu termotivasi untuk menaman padi Pandanwangi karena dari dulu petani di desa Tegallega sudah menanam padi Pandanwangi anggota kelompok tani melestarikan budidaya padi Pandanwangi meskipun pada saat ini lahan pemerintah. Kelompok tani juga termotivasi untuk menanam padi Pandanwangi karena adanya bantuan dari pemerintah seperti pupuk, alsintan dan benih jadi anggota kelompok tani termotivasi untuk menanam padi Pandanwangi.

\section{KESIMPULAN}

Kesimpulan dari penelitian ini pengaruh kepemimpinan ketua kelompok dan motivasi terhadap kinerja kelompok tani di desa Tegallega Kecamatan warungkondang :

1. Terdapat pengaruh secara signifikan dan positif dari variabel kepemimpinan terhadap kinerja kelompok tani dengan taraf signifikan sebesar $\alpha=0,10$. Dengan thitung $2.740 \quad$ lebih besar>ttabel 1.7032 dengan nilai signifikan sebesar 0,11 maka variabel kepemimpinan berpengaruh secara positif terhadap kinerja.

2. Terdapat pengaruh secara signifikan dan positif dari variabel motivasi terhadap kinerja kelompok tani dengan taraf signifikan sebesar $\alpha=0,10$. Dengan thitung 1.943 lebih besar> dari ttabel 1.7032 dengan nilai signifikan sebesar 0,63 maka variabel motivasi berpengaruh secara positif terhadap kinerja.

3. Variabel X1 (kepemimpinan) dan variabel X2 (motivasi) berpengaruh secara simultan dengan nilai Fhitung lebih besar> dari Ftabel sebesar 25,176 dengan nilai signifikan 0,000 terhadap kinerja. Artinya ketika kepemimpinan dapat memberikan motivasi untuk meningkatkan kinerja anggota kelompok tani.

\section{DAFTAR PUSTAKA}

Anwar. 2015, Analisis Kelayakan Finansial Usahatani Pandanwangi Organik di Gabungan Petani Organik (GPO) Kecamatan Cianjur Kabupaten Cianjur, UNSUR.

Arikunto. 2012. Prosedur Penelitian Suatu Pendekatan Praktek. Jakarta : Rineka Cipta.

Claveland dan Murphy. Pengaruh Tingkat Pendidikan Formal dan Disiplin Kerja Terhadap Kinerja Pegawai di Kantor Kecamatan Long Ikis Kabupaten Paser. Dalam Pesalong. 2007. (4) $4: 636$.

Fathoni. 2006. Metodologi Penelitian dan Teknik Penyusunan Skripsi. Jakarta : PT Rineke Cipta.

Ghozali, Imam. 2006. Aplikasi Analisis Multivarate Dengan Program SPSS, Semarang: Badan Penelitian Unpid.

Hasibuan, 2010. Pengaruh Motivasi Oleh Camat Terhadap Prestasi Kerja Pegawai di Kantor Camat Kecamatan Gunung Jati Kabupaten Cirebon 3.

Matondang, M.H. 2008. Kepemimpinan Karismatik Versus Kepemimpinan Transformasional. Jurnal Penelitian Hurin In Lia (1) $2: 70$

Moleong 2012. Metodelogi penelitian kualitatif. Edisi 30. Bandung. Remaja Rosdakarya.

Hasibuan, Malayu. 2009. Pengaruh Kepemimpinan dan Motivasi Kerja Karyawan Bagian Funding dan Lending Bank Bukopin Pekan Baru. (1) $2: 6$.

Materi Penyuluhan Pertanian. Penguatan Kelembagaan Petani Buku I Kelompok Tani Sebagai Kelas Belajar. Pusat Penyuluhan Pertanian. Badan penyuluhan dan Pengembangan SDM Pertanian Kementrian Pertanian.2012.

Margono. 2000. Metodologi Penelitian Pendidikan. Jakarta : Rineka Cineke.

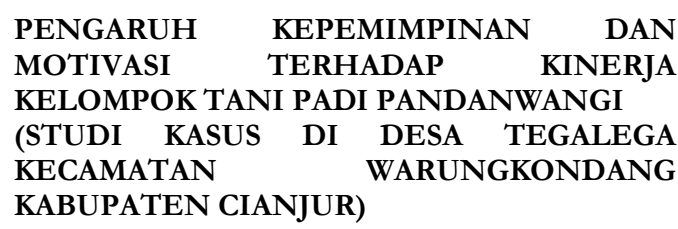


Rivai V, Mulyadi D. 2009. Kepemimpinan dalam Budaya Organisasi. Jurnal Penelitian. Jurnal Politik dan Sosial Kemasyarakatan (10) 1: 2.

Rivai.2005. Manajemen Sumberdaya Manusia. Jakarta.

Sekaran. 2004. Rasearch Methods For Business : A Skill Building Aproach,.

Sugiyono. 2015, Metode Penelitian Kombinasi. Bandung

Sugiyono. 2015, Metode Penelitian Kombinasi ( Mix Methods). Bandung: Alfabeta.

Sugiyono. 2010.Metode Penelitian Bisnis Bandung: Alfabetha

Sugiyono. 2011. .Metode Penelitian Bisnis Bandung: Alfabetha

uhardi \& Purwanto. 2004. Metode penelitian. Jakarta: Gramedia Pustaka Utama.

Suhardjo, 2007. Definisi Tingkat Pendidikan
Sudarmanto. 2009. Kinerja Pegawai Dinas Pendidikan Pemuda Dan Olahraga Kota Pekalongan. 3.

Uno. 2015. Pengaruh Motivasi dan Persepsi Tentang Pembelajaran Mata Diklat Kompetensi Kejuruan APK Terhadap Hasil Belajar Siswa di Negeri 1 Pamekasan (3) :1 3

Yukl Gary. 2009. Kepemimpinan dalam organisasi Edisi 5. ( Alih Bahasa Budi Suprianto). Jakarta: Indeks.

Weschler dan Nassarik (1961). materi pelatihan keterampilan manajerial SPMK. Dalam penelitian Stefanus Heru Prasetyo. 2015. Hubungan Perilaku Kepemimpinan Dengan Keaktifan Anggota Kelompok Tani Di Desa Sukanagalih Kecamatan Pacet Kabupaten Cianjur.

Rivai Zainal, 2014, Kepemimpinan dan Perilaku Organisasi.

\begin{tabular}{|c|c|c|}
\hline PENGARUH & KEPEMIMPINAN & DAN \\
\hline MOTIVASI & TERHADAP & KINERJA \\
\hline \multicolumn{3}{|c|}{ KELOMPOK TANI PADI PANDANWANGI } \\
\hline (STUDI & DESA & EGALEGA \\
\hline KECAMATAN & WARUNGK & ONDANG \\
\hline
\end{tabular}

